\title{
ANGIOMYOMA OF THE UPPER LIP - CASE REPORT AND REVIEW OF THE LITERATURE
}

\author{
Berislav Perić ${ }^{1}$, BrunoVidaković 2 , Nino Grgić 3 , Spomenka Manojlović ${ }^{4}$ and Hrvoje Čavka ${ }^{5}$ \\ ${ }^{1}$ Department of Oral and Maxillofacial Surgery, Dubrava University Hospital, \\ School of Dental Medicine, University of Zagreb, Zagreb, Croatia; \\ ${ }^{2}$ Department of Otorhinolaryngology and Head and Neck Surgery, Dr. Josip Benčević General Hospital, \\ Slavonski Brod, Croatia; ${ }^{3}$ Department of Oral and Maxillofacial Surgery, Dubrava University Hospital, \\ School of Dental Medicine, University of Zagreb, Zagreb, Croatia; \\ ${ }^{4}$ Department of Clinical and Experimental Pathology, Dubrava University Hospital, Zagreb, Croatia; \\ ${ }^{5}$ Čavka Private Dental Office, Mursko Središće, Croatia
}

\begin{abstract}
SUMMARY - A case is presented of upper lip angiomyoma in a 36-year-old man. The tumor was painless, palpable and clinically visible. The operation was performed under local anesthesia in the Outpatient Department. There were no complications during the postoperative course. Current literature on the subject is listed in the introduction, followed by presentation of the case and histologic characteristics of the tumor. This case is described as one of the differential diagnostic possibilities in the diagnosis of soft tissue tumors of the lip. Also, through review of the literature, different clinical appearances of angiomyoma, histologic variations and immunohistochemical characteristics are discussed that can help identify this tumor.
\end{abstract}

Key words: Angiomyoma; Lip neoplasms; Soft tissue neoplasms; Mouth; Anesthesia, local; Case reports

\section{Introduction}

Angiomyomas are benign tumors of the smooth muscles classified as a subtype of leiomyomas. They are infrequent in the oral cavity. Blanc reported the first case of oral leiomyoma in $1884^{1}$. According to Barnes, leiomyomas are classified into four subtypes: leiomyoma (simple, conventional or common), angiomyoma (angioleiomyoma, vascular leiomyoma), epithelioid leiomyoma (bizarre leiomyoma, leiomyoblastoma) and mesectodermal leiomyoma. Barnes investigated 257 leiomyomas of the head and neck, $27 \%$ of which were angioleiomyomas, $1.2 \%$ epithelioid, $0.8 \%$ mesectoder$\mathrm{mal}$, and $71 \%$ were the most frequent simple or common leiomyomas. Out of 69 angiomyomas of the head

Correspondence to: Berislav Perić, DMD, PhD, Department of Oral and Maxillofacial Surgery, Dubrava University Hospital, School of Dental Medicine, University of Zagreb, Av. Gojka Suška 6, HR-10000 Zagreb, Croatia

E-mail: berislav.peric@kbd.hr

Received March 15, 2016, accepted October 27, 2016 and neck, 31 were reported to be in the area of the oral cavity, 13 affecting the lips, 8 the soft palate, 5 the tongue, 3 buccal mucosa, 1 gingiva and 1 the uvula. The others were located in the skin of the head and neck and in the area of the nasal cavity, larynx, etc ${ }^{2}$. Regarding the distribution of leiomyomas in all areas of the body, Farman reports that $95 \%$ of leiomyomas were situated in the female genital tract, $3 \%$ in the skin, and $1 \%$ in the gastrointestinal tract and other parts of the body ${ }^{3}$. Tumors occur in middle and older age, and although they are somewhat more frequent in women, gender prevalence cannot be confirmed on the basis of the few series of leiomyomas of the head and neck in the literature. Current literature describes small series or individual cases in the area of oral cavity and jaws ${ }^{4}$, some of which were small and the others were of such a size that an extra oral approach under general anesthesia was indicated ${ }^{5}$. We report a rare case of angiomyoma of the upper lip surgically treated under local anesthesia. 


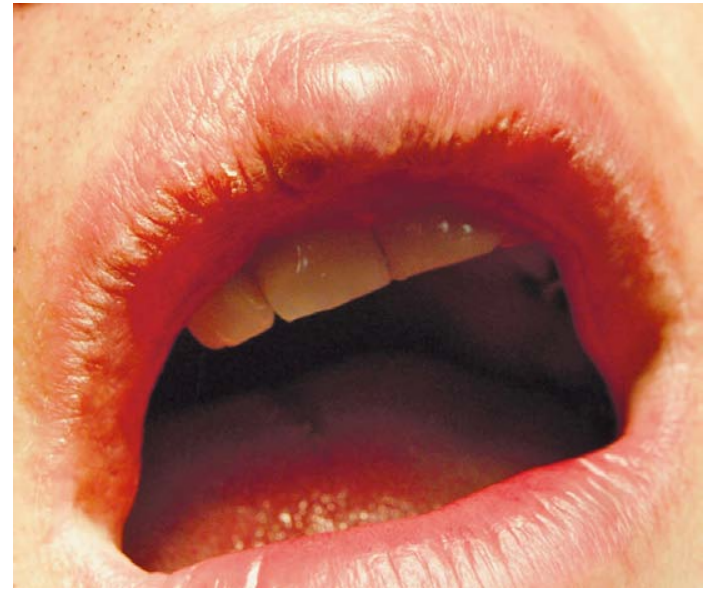

Fig. 1. Clinical appearance of a growth on the upper lip.

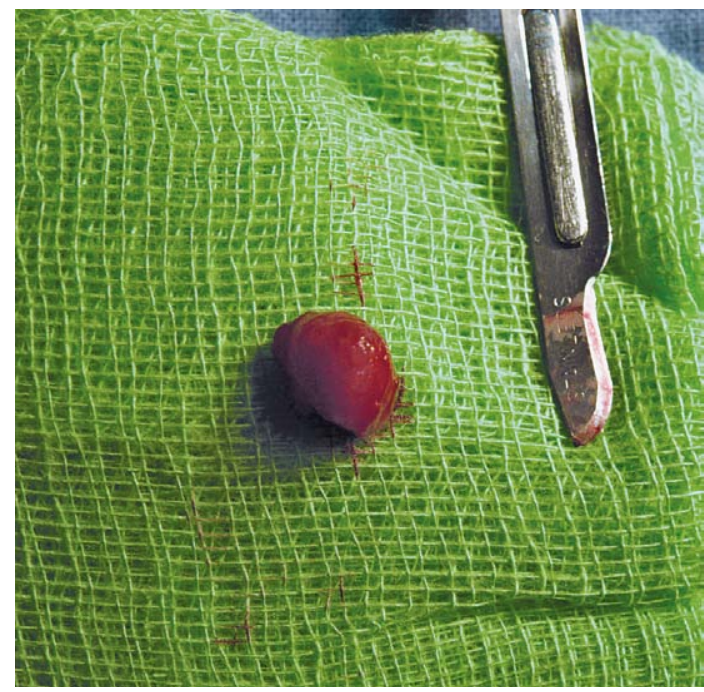

Fig. 2. Tumorous alteration after excision.

\section{Case Report}

A 36-year-old man was referred to the Division of Oral Surgery, Department of Maxillofacial and Oral Surgery because of painless swelling in the upper lip, observed for two years and gradually increasing in size (Fig. 1). A sharply circumscribed oval mass, $5 \times 3 \mathrm{~mm}$ in size, was clinically visible, painless and moveable under the mucous membrane of the lip. The patient denied trauma in the facial area. Upon obtaining consent, excisional biopsy was performed under local anesthesia. The surgical specimen was a smooth, grayish-brown, oval nodule, measuring $5 \mathrm{~mm}$ in diameter (Fig. 2). Follow up examination 7 days after excision showed normal healing of the wound.

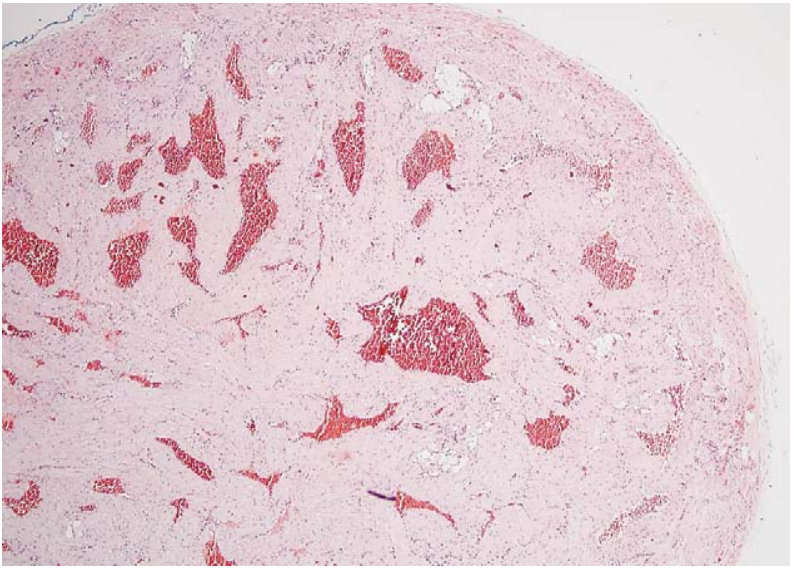

Fig. 3. The tumor composed of a numerous thick-walled vessels with slit-like and dilated lumina (HE X40).

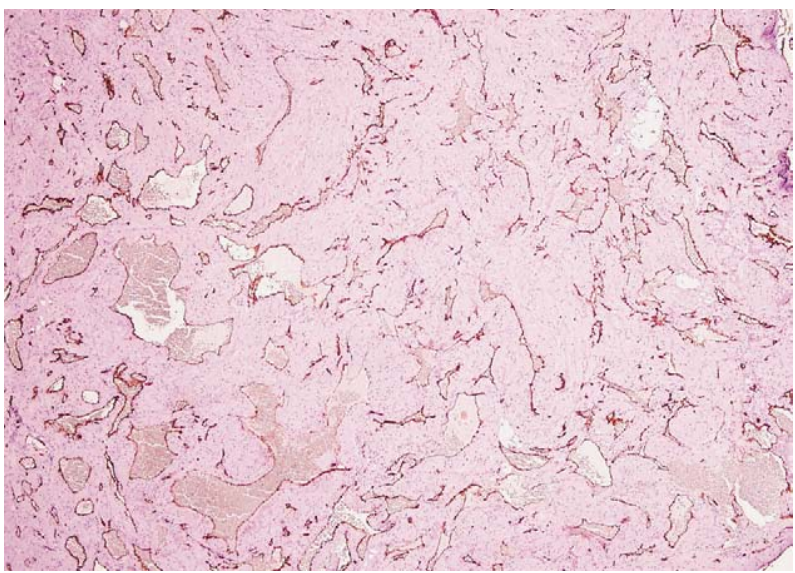

Fig. 4. Immunohistochemically positive CD 34 endothelial cells (streptavidin biotinylated immunoperoxidase, X40).

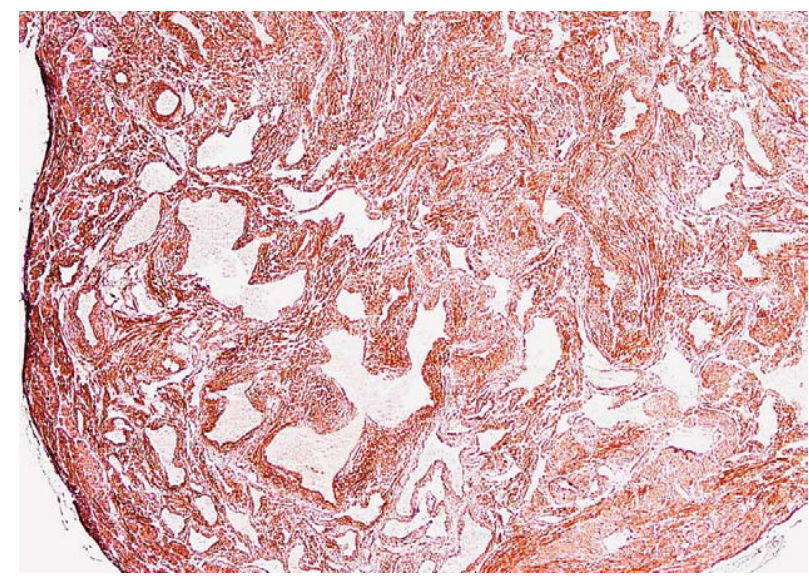

Fig. 5. Immunohistochemically positive smooth muscle actin in the vessel walls (streptavidin biotinylated immunoperoxidase, X40). 
Histopathologic analysis revealed a tumor composed of numerous thick-walled vessels with partially patent, and partially collapsed lumina (Fig. 3), layered by intact endothelial cells, expressing CD 34 immunohistologic positivity (Fig. 4). The vessel walls consisted of smooth muscle fibers arranged circumferentially in the inner, and swirled in the outer layers, confirmed by immunohistologic expression of smooth-muscle actin (Fig. 5). The diagnosis was angiomyoma.

\section{Discussion}

The case presented was located in the upper lip. Histologically, angiomyomas are classified in three types, solid, cavernous and venous ${ }^{6}$, depending on the appearance of the blood vessels, which may be slit-like, dilated, with smaller smooth muscle components, or more vein-like than artery-like. In the case presented, the thick-walled vessels with small lumina were reminiscent of arteries, but they lacked elastic lamina, and the cavernous-type vessels were reminiscent of veins. Therefore, the histologic pattern of the tumor did not fit any of the above-mentioned types of angiomyomas. The histologic pattern of angiomyoma does not predict biological behavior of the lesion, and this classification is rather of academic interest.

Differential diagnosis includes keloid scar, mucocele, salivary gland tumor (most likely canalicular adenoma of a small salivary gland within the lip), lipoma, neurilemmoma and neurofibroma (clinically reminiscent of angiomyoma, but immunohistochemically different), and possibly granular cell tumor.

Sauerborn et al. and Vormittag et al. showed that metastases of malignant tumor should also be considered on differential diagnosis ${ }^{7,8}$.

Recurrence and malignant alterations of angiomyomas are extremely rare. The final outcome is related to the size of angiomyoma, smaller than $5 \mathrm{~cm}$, sparse mitotic activity in the histopathologic sample, abundant cytoplasm, prominent reticulin fibers, and lack of inva$\operatorname{sion}^{2}$. No element to suggest alteration of the tumor was found in the case presented. There are cases that grow exophytically and resemble fibro-epithelial polyps. Koca et al. have described a very rare localization of the tumor in the retromolar region of the mandible. The tumor clinically resembled an epulis and caused bone resorption. Furthermore, due to pressure of the mass, third molar changed its localization and angulation'. Hung et al. also describe similar localization in the lingual gingiva of the mandible ${ }^{10}$. A bizarre case of angioleiomyoma in the inferior nasal turbinate, which caused epistaxis and nasal obstruction for several years, has been described by $\mathrm{He}$ et al. ${ }^{11}$. Among unusual localizations was a case of angioleiomyoma in the hard palate $^{12}$ and in the cheek ${ }^{13}$. Cases have been reported in which leiomyomas caused a painful sensation ${ }^{14}$. Morimoto has divided angiomyomas into two groups according to painful symptoms; the first group are extremity tumors which are usually solid and painful, and the second group are head tumors, mainly of the venous type and thus painless ${ }^{15}$. Hachisuga et al. report pain as a frequent symptom of angioleiomyoma. In a sample of 562 patients, the tumors caused pain and tenderness in 327 (58\%) cases, 262 of which were solid tumors and appeared on extremities. Tumors in the head region usually were not painful ${ }^{6}$. Ramesh et al. believe that pain occurs due to the contraction of smooth muscles, which induces ischemia, or because of ischemia in the area of the tumor induced by thrombosis. Another explanation of pain is the accumulation of blood in the tumor during effort which strains the capsule and the nerve endings within it. However, pain disappears at rest ${ }^{16}$. Because several other oral tumors have clinical appearance like angiomyoma, definitive diagnosis should be histologically determined. Leiomyosarcoma should be taken into account when histologic features show nuclear pleomorphism and atypia, necrosis and mitotic activity greater than 2 mitoses per 10 high power fields ${ }^{17}$. It is difficult to diagnose leiomyoma only through examination on hematoxylin and eosin tissue section. To confirm the diagnosis and to rule out other soft tissue neoplasms, particularly spindle cell tumors, we need immunohistochemical analysis. Leiomyomas show positive reactivity against desmin, alpha smooth muscle actin and vimentin ${ }^{4}$. CD34 antigen is a protein that is expressed by vascular endothelium, endothelium progenitor cells and mesenchymal stem cells ${ }^{18}$. Capillaries show strongest expression, followed by other types of blood vessels ${ }^{19}$. Nakayama et al. suggest that deficiency in positive CD34 stromal cell protein expression, which has been reported in different cases ${ }^{4,20,21}$, can be related to pathologic condition or tumor structure ${ }^{22}$.

The case presented is an interesting and unusual localization of angiomyoma which may cause differential diagnostic difficulties. As an inappropriate surgical excision may cause bleeding, clinicians should be aware of and take into account the possible occurrence of this rare tumor. 


\section{References}

1. Blanc E. Travaux originaux. Gaz Hebd Med Chir. 1884;21:611.

2. Barnes L. Tumors and tumor like lesions of soft tissue. In: Barnes L, editor. Surgical Pathology of Head and Neck. $2^{\text {nd }}$ edn. New York: Marcel Dekker; 2001; p. 912-5.

3. Farman AG. Benign smooth muscle tumours. S Afr Med J. 1975;49(33):1333-40.

4. Gaitan Cepeda LA, Quezada Rivera D, Tenorio Rocha F, Leyva Huerta ER, Mendez Sánchez ER. Vascular leiomyoma of the oral cavity. Clinical, histopathological and immunohistochemical characteristics. Presentation of five cases and review of the literature. Med Oral Patol Oral Cir Bucal. 2008;13(8): E483-8.

5. Keerthi R, Nanjappa M, Deora SS, Kumaraswamy SV. Angioleiomyoma of cheek: report of two cases. J Maxillofac Oral Surg. 2009;8(3):298-300. doi: 10. 1007/s12663-009-0073-0.

6. Hachisuga T, Hashimoto H, Enjoji M. Angioleiomyoma. A clinicopathologic reappraisal of 562 cases. Cancer. 1984;54 (1):126-30. doi.org/10.1002/1097-0142(19840701).

7. Sauerborn D, Vidakovic B, Baranovic M, Mahovne I, Danic P, Danic D. Gastric adenocarcinoma metastases to the alveolar mucosa of the mandible: a case report and review of the literature. J Craniomaxillofac Surg. 2011;39(8):645-8. doi:10.1016/j.jcms.2010.10.020

8. Vormittag L, Erovic B, Schopper C, Zielinski CC, Kornek G, Thurnher D. Unilateral face swelling as first manifestation of metastatic pancreatic cancer: case report and review of the literature. Wien Klin Wochenschr. 2008;120(21-22):693-6. doi: 10.1007/s00508-008-1084-4.

9. Koca H, Güneri P, Çetingül E, Önal T. A very rare form of leiomyoma: mandibular angioleiomyoma. Int J Pediatr Otorhinolaryngol Extra. 2006;1(2):110-4. Available from: http:// www.ijporlextra.com/article/S1871-4048(06)00031-1/

10. Hung KF, Yan AH, Kao SY, Chang CS. Angioleiomyoma in the right lingual gingiva - a case report. Chin J Oral Maxillofac Surg. 2005;16:179-87.
11. He J, Zhao L-N, Jiang Z-N, Zhang S-Z. Angioleiomyoma of the nasal cavity: a rare cause of epistaxis. Otolaryngol Head Neck Surg. 2009;141(5):663-4. doi: $10.1016 /$ j.otohns.2009.04.003

12. Al-Amad SH, Angel C, O'Grady JF, McCullough MJ. Angioleiomyoma on the hard palate. Oral Oncology Extra. 2006; 42(6):244-6

13. Vidaković B, Kotarac Knežević A, Manojlović S, Knežević G. Angiomyoma - angioleiomyoma of the cheek. Coll Antropol. 2011;35(1):207-9.

14. Toida M, Koizumi H, Shimokawa K. Painful angiomyoma of the oral cavity: report of a case and review of the literature. J Oral Maxillofac Surg. 2000;58(4):450-3. doi.org/10.1016/S0278-2391(00)90935-2.

15. Morimoto N. Angiomyoma (vascular leiomyoma): a clinicopathological study. Med J Kagoshima Univ. 1973;24:663-83.

16. Ramesh P, Annapureddy S, Khan F, Sutaria P. Angioleiomyoma: a clinical, pathological and radiological review. Int J Clin Pract. 2004;58(6):587-91.

17. Kumar V, Cotran RI. Robbins Basic Pathology. $7^{\text {th }}$ edn. Philadelphia: Elsevier, 2004; p. 1090.

18. Lin G, Finger E, Gutierrez-Ramos JC. Expression of CD34 in endothelial cells, hematopoietic progenitors and nervous cells in fetal and adult mouse tissues. Eur J Immunol. 1995 Jun;25(6):1508-16. doi: 10.1002/eji.1830250606

19. Pusztaszeri MP, Seelentag W, Bosman FT. Immunohistochemical expression of endothelial markers CD31, CD34, von Willebrand factor, and Fli-1 in normal human tissues. J Histochem Cytochem. 2006;54(4):385-95. doi: $10.1369 /$ jhc.4A6514.2005.

20. Alvarez E, Laberry MP, Ardila CM. Multiple oral leiomyomas in an infant: a rare case. Case Rep Dent. 2012;2012:1-3.

21. Osano H, Ioka Y, Okamoto R, Nakai Y, Hayashi H, Tsuchiya $\mathrm{Y}$, et al. Angioleiomyoma of the cheek: a case report.J Oral Sci. 2015;57(1):63-6. doi:10.2334/josnusd.57.63.

22. Nakayama H, Enzan H, Miyazaki E, Kuroda N, Toi M. Lack of CD34 positive stromal cells within angiomyomas (vascular leiomyomas). J Clin Pathol. 2002;55(5):395-6.

Sažetak

\section{ANGIOM GORNJE USNE - PRIKAZ SLUČAJA I PREGLED LITERATURE}

\section{B. Perić, B. Vidaković, N. Grgič, S. Manojlović i H. Čavka}

Autori prikazuju slučaj angiomioma gornje usne kod muškarca u dobi od 36 godina. Tumor je bio bezbolan, palpabilan i klinički vidljiv. Operacija je učinjena ambulantno u lokalnoj anesteziji. Poslijeoperacijski tijek je bio uredan. Postojeća literatura o temi je prikazana u uvodu te je potom popraćena prikazom slučaja kao i histološkim karakteristikama prikazanog tumora. Ovaj se slučaj opisuje kao jedna od diferencijalno dijagnostičkih mogućnosti kod mekotkivnih tumora usne. Također, kroz pregled literature pokazuju se različite kliničke i histološke varijacije tumora kako bi se što lakše dijagnosticirao.

Ključne riječi: Angiomiom; Usna, tumori; Meko tkivo, tumori; Usta; Anestezija, lokalna; Prikazi slučaja 